\title{
PERBEDAAN INFORMASI ANATOMI CITRA MRI CERVICAL PADA KASUS HERNIA NUCLEUS PULPOPUS (HNP) DENGAN SEKUEN T2W FAST SPIN ECHO (FSE) ANTARA PENGGUNAAN FLOW COMPENSATION DAN TANPA FLOW COMPENSATION
}

\author{
1) Nidaa Azmii Susdiningtyas ${ }^{2)}$ Farrah Hendara Ningrum ${ }^{3)}$ Nanang Sulaksono ${ }^{4)}$ Sudiyono \\ ${ }^{133) 4)}$ Department of Radiodagnostic and Radiotherapy Technique, Poltekkes Kemenkes Semarang, Indonesia \\ 2) Radiologist at Kariadi Hospital Semarang \\ Email : nidaa19azmii@gmail.com
}

Prodi D-IV Teknik Radiologi Semarang ; Poltekkes Kemenkes Semarang

\begin{abstract}
Background : Flow compensation is one technique that can reduce artifacts due to the flow of cerebrospinal fluid in MRI examination of the cervical in cases of Hernia Nucleus Pulposus specifically in T2 Weighted Fast Spin Echo (FSE) sequence images.

Method : This research is quantitative study with an experimental approach. This study using 10 pasient at Cempaka Putih Hospital in Jakarta. Wilcoxon test to determine the level of cervical MRI anatomical information distribution in the case of HNP between using flow compensation and without flow compensation, mean rank value to get the better image information.

Result : From the results of statistical tests, it is known that there are differences in Cervical MRI image information in the HNP case with the T2W FSE between the use of flow compensation and without flow compensation as indicated by the p-value 0.000 ( $p$-value $\leq 0.05$ ), this difference is due to flow compensation which can suppress flow artifacts on objects resulting in a better picture. The mean rank value in the overall anatomy of the MRI Cervical MRI image shows a better value using flow compensation with the highest value in the anatomy of the intervertebral disc, CSF, and spinal cord, 5.00 in axial view. Whereas the sagittal view in the anatomy of the vertebral corpus and spinal cord show the same value between using flow compensation and without flow compensation.
\end{abstract}

Conclusion : There are differences in overall anatomical image information of MRI Cervical using flow compensation and without Flow compensation except corpus vertebralis and spinal cord in sagital view.

Keyword : flow artefact, flow compensation, T2 Weigthed, MRI Cervical, HNP

\section{Pendahuluan}

Penyakit Hernia Nucleus Pulposus (HNP) merupakan turunnya kandungan annulus fibrosus dari diskus intervertebralis pada spinal cord dengan tekanan dari nukleus pulposus yang menyebabkan kompresi pada elemen saraf [Lotke P, et all, 2008]. HNP secara umum dapat terjadi di vertebra cervical, thoracal, dan lumbal. HNP pada daerah cervikal dapat terjadi akibat proses degeneratif maupun trauma yang mencederai vertebra cervikalis. Proses degeneratif dan trauma ini menyebabkan perubahan pada struktur diskus intervertebralis yang terletak diantara masing-masing badan (corpus) vertebra cervikalis, sehingga fungsinya sebagai penahan tekanan (shock absorbers) terganggu dan menyebabkan substansi diskus keluar (herniasi) hingga menekan radix saraf bahkan medula spinalis.
Untuk menegakkan diagnosa pada klinis HNP dapat digunakan beberapa modalitas radiologi diantaranya pesawat radiologi konvensional, Computed Tomography (CT) Scan, dan Magnetic Resonance Imaging (MRI). Modalitas MRI digunakan sebagai penunjang diagnosa HNP karena memiliki kelebihan terutama dalam menampakkan soft tissue. Magnetic Resonance Imaging (MRI) memanfaatkan medan magnet untuk dapat menampakkan struktur anatomi tubuh manusia. Sensitivitas kontras yang tinggi terhadap perbedaan jaringan lunak dan keamanan terhadap pasien dihasilkan dari penggunaan radiasi non ionisasi telah menjadi alasan utama mengapa MRI telah banyak menggantikan banyak metode CT dan proyeksi radiografi [Busherg, J, 2012]. 
Pada pemeriksaan MRI sering kali terdapat artefak yang disebabkan oleh pergerakan pasien, benda logam, pergerakan dari aliran darah dan cairan cerebrospinal atau gerakan yang terjadi secara tidak periodik seperti gerakan menelan pada daerah vertebra cervical. Pada daerah vertebra cervical kecepatan aliran CSF cukup tinggi dan bidang gambaran tegak lurus dengan arah aliran. Artefak yang disebabkan karena pergerakan ini menyebabkan area gambaran menjadi buram karena loss signal [Fieldstrength, 2013].

Terdapat beberapa teknik yang dapat digunakan untuk mengurangi adanya artefak yaitu dengan ECG gating, respiratory gating, dan saturation band. ECG gating dan respiratory gating merupakan salah teknik yang dapat digunakan untuk mengurangi artefak akibat adanya aliran pulsasi carotid atau aliran CSF pada tulang belakang namun teknik ini cukup sulit dan membutuhkan waktu yang cukup lama. Sedangkan pada saturation band terdapat kelemahan yaitu karena saturation band diterapkan pada awal urutan pulsa, ketika laju penyerapan sudah tinggi dapat menghasilkan pengendapan panas yang berlebihan [RungeVal, et all, 2011].

Maka dari itu peneliti menawarkan teknik yang cukup efektif dalam mengurangi artefak pada daerah yang terdapat aliran darah dan csf yaitu dengan menggunakan flow compensation. Flow compensation atau Gradient Moment Nulling (GMN) merupakan salah satu metode untuk meminimalkan artefak yang dikarenakan pergerakan aliran seperti pada CSF. Flow compensation dapat mengurangi artefak signal loss dan ghosting yang terjadi ketika ada aliran, pulsasi atau gerakan periodik [Covington and Mattew, 2017].

Flow compensation atau gradient momen nulling atau biasa disebut dengan istilah motion artifact suppression technique (MAST) adalah teknik untuk mengurangi artefak pulsatile flow dengan menambahkan pulsa gradient tambahan pada sekuens pulsa untuk mengkoreksi phase shift karena pergerakan dari proton-proton [Dale, et all, 2015].

\section{Metode}

Jenis penelitian yang dilakukan adalah penelitian kuantitatif dengan pendekatan eksperimen.Percobaan dilakukan untuk menguji perbedaaan informasi anatomi citra MRI Cervical pada kasus HNP antara penggunaan flow compensation dan tanpa menggunakan flow compensation pada potongan axial dan sagital. Penelitian ini dilakukan di RSIJ Cempaka Putih dan pengambilan data dilakukan pada bulan Maret sampai dengan April 2019.

Subjek penelitian ini adalah 3 orang dokter spesialis radiologi dengan inklusi pengalaman lebih dari 5 tahun dalam menginterpretasi gambaran MRI Cervical dengan sekuan T2W FSE potongan axial dan sagital. Dokter spesialis radiologi bertindak sebagai responden dalam penelitian.

Data merupakan data ordinal dari hasil kuisoner dokter spesialis radiologi mengenai anatomi pada MRI Cervical. Hasil penilaian lalu dilakukan uji cohen's kappa untuk menilai kesepakatan antar ketiga responden. Untuk mengetahui perbedaan informasi anatomi citra dilakukan dengan analisa tingkat kepercayaan dengan nilai $p$-value $<0,05$ maka Ho ditolak dan Ha diterima. Apabila p-value >0,05 maka Ho diterima dan Ha ditolak. Setelah itu dilakukan uji Wilcoxon untuk mengetahui informasi anatomi mana yang lebih baik antara penggunaan flow compensation atau tanpa menggunakan flow compensation dengan mendeskripsikan mean rank hasil uji statistik Wilcoxon. Informasi anatomi yang paling baik ditandai dengan nilai mean rank yang tertinggi.

\section{Hasil dan Pembahasan}

Dari hasil penelitian yang telah dilakukan di Instalasi Radiologi Rumah Sakit Islam Jakarta Cempaka Putih pada bulan MaretApril 2019, digunakan 10 sampel penelitian dengan berdasarkan jenis kelamin yaitu pasien perempuan berjumlah 5 orang dan pasien lakilaki berjumlah 5 orang. Rentang umur pasien adalah dari 41 s.d. 65 tahun.

Penelitian ini menghasilkan 6 citra yaitu 2 citra MRI cervical T2W FSE potongan axial dan 4 citra MRI cervical T2W FSE potongan sagital ditujukkan oleh gambar 1 dan gambar 2 .

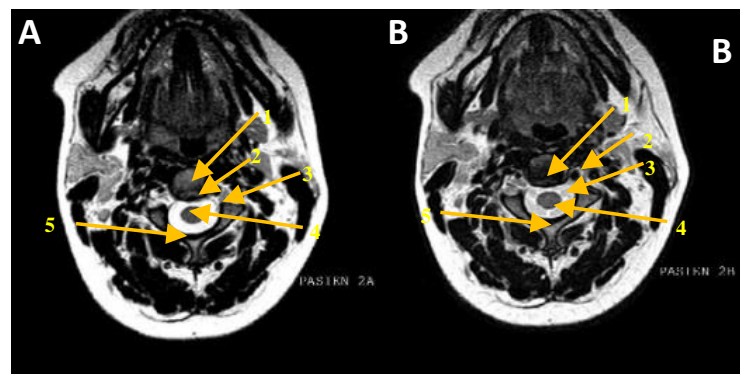

Keterangan :

1. Diskus Intervertebrais

2.Hernia Nucleus Pulposus

3. Cerebrospinal fluid
4, spinal cord

5. ligamentum flavum 
Gambar 1 Citra Anatomi MRI Cervical T2W

FSE potongan axial (a) tanpa flow compensation (b) dengan flow compensation

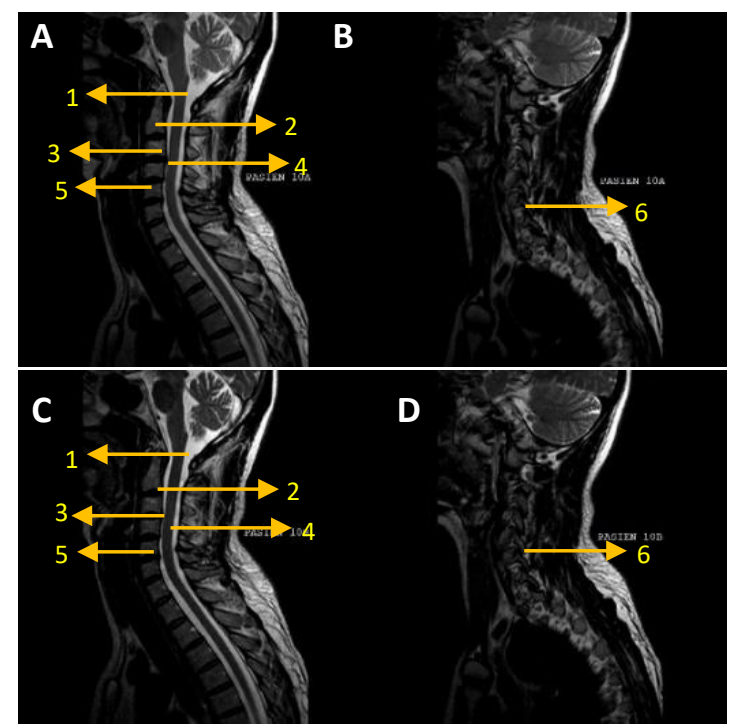

Keterangan :

1. Cerebrospinal fluid 4. Hernia Nucleus

2. Corpus vertebralis Pulposus
3. Diskus
5. Spinal cord

Intervertebralis

6. Nerve root

Gambar 2 Citra Anatomi MRI Cervical T2W

FSE potongan axial (a) tanpa flow compensation mid sagital view (b) tanpa flow compensation para sagital view (c) dengan flow compensation mid sagital view (d) dengan flow compensation para sagital view

Hasil uji kappa menunjukkan kesepakatan yang baik antar 3 responden baik pada potongan axial dimana nilai yang tertinggi potongan axial yaitu 0,712 pada responden 2 dan 3 yang menggunakan flow compensation, sedangkan yang tidak menggunakan flow compensation didapatkan nilai tertinggi yaitu 0,821 pada responden 1 dan 2 . Pada potongan sagital juga didapatkan hasil uji kappa yang baik dimana nilai tertinggi yaitu 0,784 pada responden 2 dan 3 yang menggunakan flow compensation, sedangkan yang tidak menggunakan flow compensation didapatkan nilai tertinggi yaitu 0,650 pada responen 2 dan 3 .

1. Hasil uji beda untuk mengetahui perbedaan dari penggunaan flow compensation dan tanpa menggunakan flow compensation pada potongan axial dan sagital yang ditunjukkan pada tabel 1.
Tabel 1 perbedaan informasi anatomi potongan axial

\begin{tabular}{ccc}
\hline $\begin{array}{c}\text { Informasi } \\
\text { Anatomi }\end{array}$ & $\mathrm{p}$-value & Keterangan \\
\hline $\begin{array}{c}\text { Diskus } \\
\text { Intervertebralis } \\
\text { Cerebrospinal }\end{array}$ & 0,03 & Ada beda \\
Fluid & 0,03 & Ada beda \\
$\begin{array}{c}\text { Spinal Cord } \\
\text { Ligamentum }\end{array}$ & 0,03 & Ada beda \\
Flavum & 0,014 & Ada beda \\
HNP & 0,02 & Ada beda \\
Artefak & 0,034 & Ada beda \\
\hline
\end{tabular}

Tabel 2 perbedaan informasi anatomi potongan sagital

\begin{tabular}{|c|c|c|}
\hline Informasi Anatomi & p-value & Keterangan \\
\hline Corpus Vertebalis & 0,180 & $\begin{array}{l}\text { Tidak ada } \\
\text { beda }\end{array}$ \\
\hline $\begin{array}{c}\text { Diskus } \\
\text { Intervertebralis }\end{array}$ & 0,046 & Ada beda \\
\hline Cerebrospinal Fluid & 0,014 & Ada beda \\
\hline Spinal Cord & 0,564 & $\begin{array}{l}\text { Tidak ada } \\
\text { beda }\end{array}$ \\
\hline Nerve root & 0,008 & Ada beda \\
\hline HNP & 0,046 & Ada beda \\
\hline Artefak & 0,035 & Ada beda \\
\hline
\end{tabular}

Hasil uji Wilcoxon menunjukkan terdapat beda signifikan penggunaan flow compensation dengan tanpa menggunakan flow compensation pada potongan axial dan sagital dengan nilai $p$-value 0,000 (pvalue $\leq 0,05$ ).

Untuk mengetahui anatomi citra yang lebih baik antara penggunaan flow compensation dan tanpa flow compensation maka dapat dilihat nilai mean rank dari uji Wilcoxon

2. Hasil mean rank untuk mengetahui perbedaan dari penggunaan flow compensation dan tanpa menggunakan flow compensation pada potongan axial dan sagital yang ditunjukkan pada tabel 3 .

Tabel 3 hasil uji mean rank pada citra

MRI Cervical antara menggunakan flow compensation dan tanpa flow compensation pada potongan axial dan sagital

\begin{tabular}{ccc}
\hline & $\begin{array}{c}\text { Flow } \\
\text { compensation }\end{array}$ & Mean rank \\
\hline Potongan & ya & 24,00 \\
Axial & tidak & 0,00 \\
\hline Potongan & ya & 18,69 \\
sagital & tidak & 17,00 \\
\hline
\end{tabular}

Berdasarkan tabel diatas dapat diketahui nilai mean rank dengan menggunakan flow 
compensation lebih baik dibandingkan tanpa menggunakan flow compensation.

Tabel 4 hasil mean rank uji mean rank pada citra MRI Cervical antara menggunakan flow compensation dan tanpa flow compensation pada potongan axial

\begin{tabular}{lcc}
\hline \multicolumn{1}{c}{ Informasi } & $\begin{array}{c}\text { Flow } \\
\text { Anatomi }\end{array}$ & $\begin{array}{c}\text { Mean } \\
\text { compensation }\end{array}$ \\
\hline Diskus & ya & 5,00 \\
Intervertebralis & Tidak & 0,00 \\
Cerebrospinal & ya & 5,00 \\
fluid & Tidak & 0,00 \\
Spinal cord & ya & 5,00 \\
& Tidak & 0,00 \\
Ligamentum & ya & 3,50 \\
flavum & Tidak & 0,00 \\
HNP & ya & 5,50 \\
& Tidak & 0,00 \\
Artefak & ya & 3,00 \\
& Tidak & 0,00 \\
\hline
\end{tabular}

Berdasarkan tabel di atas hasil mean rank uji Wilcoxon pada citra MRI Cervical antara menggunakan flow compensation dan tanpa flow compensation pada potongan axial pada masingmasing anatomi dengan menggunakan flow compensation memiliki nilai mean rank yang lebih tinggi dibandingkan tanpa menggunakan flow compensation.

Tabel 5 hasil mean rank uji mean rank pada citra MRI Cervical antara menggunakan flow compensation dan tanpa flow compensation pada potongan sagital

\begin{tabular}{lcc}
\hline \multicolumn{1}{c}{ Informasi } & Flow & Mean \\
\multicolumn{1}{c}{ Anatomi } & compensation & rank \\
\hline Corpus & ya & 3,00 \\
Vertebralis & Tidak & 3,00 \\
Diskus & ya & 2,50 \\
Intervertebralis & Tidak & 0,00 \\
Cerebrospinal & ya & 3,50 \\
fluid & Tidak & 0,00 \\
Spinal cord & ya & 2,00 \\
& Tidak & 2,00 \\
Nerve root & ya & 0,00 \\
& Tidak & 4,00 \\
HNP & ya & 2,50 \\
& Tidak & 0,00 \\
Artefak & ya & 4,57 \\
& Tidak & 4,00 \\
\hline
\end{tabular}

Berdasarkan tabel di atas hasil mean rank uji Wilcoxon pada citra MRI Cervical antara menggunakan flow compensation dan tanpa flow compensation pada potongan sagital pada anatomi diskus intervertebralis, cerebrospinal cord, nerve root, penilaian HNP dan artefak dengan menggunakan flow compensation memiliki nilai mean rank yang lebih tinggi dibandingkan tanpa menggunakan flow compensation. Sedangkan pada anatomi corpus vertebralis dan spinal cord menunjukkan nilai yang sama antara penggunaan flow compensation dan tanpa flow compensation

3. Perbedaan informasi anatomi citra MRI Cervical pada kasus hernia nucleus pulpopus (HNP) dengan sekuen T2W fast spin echo (FSE) antara penggunaan flow compensation dan tanpa flow compensation

Potongan axial yang digunakan pada penelitian ini yaitu pada potongan yang terdapat gambaran HNP saja, sedangkan pada potongan sagital pada potongan mid sagital dan para sagital. Digunakan dua potongan pada penelitian ini yaitu axial dan sagital, karena pada kasus HNP potongan wajib yang dilakukan pada protokol pemeriksaan MRI adalah potongan sagital yang kemudian didukung dengan potongan axial untuk menegakkan diagnosa. Potongan axial digunakan untuk melihat adanya kompresi pada spinal cord dapat didefinisikan berdasarkan keberadaan dari CSF di sekitar spinal cord yang dapat dilihat jelas pada MRI axial T2. Potongan Sagital digunakan untuk melihat jenis dari tonjolan nucleus pulposus [Hussain, M, 2012]

Pada hasil penelitian diketahui bahwa yang menggunakan flow compensation lebih baik dalam menunjukkan informasi anatomi secara umum karena berkurangnya flow artefak. Hal ini sesuai dengan proses flow compensation yang digunakan untuk mengurangi aliran artefak dalam gambar dan intravoxel dephasing. Tujuan dari pemberian flow compensation untuk rephase aliran dalam pembuluh darah [Blink and Evert J, 2004]

Pada potongan sagital tabel 2 anatomi diskus intervertebralis, cerebrospinal fluid, dan nerve root serta pada penliaian HNP dan artefak terdapat beda signifikan antara menggunakan dan tanpa menggunakan flow compensation. Namun, pada daerah corpus vertebralis dan spinal cord tidak ada beda signifikan antara menggunakan flow compensation dan tanpa menggunakan flow compensation. Tidak adanya perbedaan pada daerah tersebut dikarenakan pemberian flow compensation hanya fokus memperbaiki gambaran pada gerakan aliran 
yang memiliki kecepatan atau percepatan [A. DG, 2001]

4. Anatomi citra paling baik pada MRI Cervical kasus hernia nucleus pulpopus (HNP) dengan sekuen T2W fast spin echo (FSE) antara penggunaan flow compensation dan tanpa flow compensation

Berdasarkan hasil uji statistik tabel 3 mean rank potongan axial dan sagital secara umum dengan menggunakan flow compensation lebih baik dalam menampakkan anatomi citra MRI Cervical.

Berdasarkan tabel 4 pada hasil mean rank potongan axial diskus intervertebralis, spinal cord, cerebrospinal fluid, ligamentum flavum, penilaian HNP dan penilaian artefak yang menggunakan flow compensation memiliki nilai yang lebih tinggi dibandingkan tanpa menggunakan flow compensation. Dimana nilai tertinggi yaitu pada anatomi spinal cord, cerebrospinal fluid dan pada penilaian HNP yaitu 5,00. Maka penggunaan flow compensation dapat memperlihatkan citra anatomi citra MRI Cervical yang lebih baik dan dapat mengurangi adanya flow artefak ataupun ghosting artefak dikarenakan adanya aliran csf yang cukup tinggi pada daerah cervical. Pada penilaian HNP juga dapat lebih akurat karena citra dapat terlihat lebih baik karena berkurangnya artefak. Pengaplikasian flow compensation dapat mengurangi motion artefak dan meningkatkan sinyal dari csf dan vascular. Secara keseluruhan kualitas citra dapat meningkat dan meningkatkan diagnosis [Pattany, 1987]

Berdasarkan tabel 5 hasil mean rank potongan sagital pada anatomi diskus intervertebralis, cerebrospinal fluid, nerve root, penilaian HNP dan artefak yang menggunakan flow compensation memiliki nilai yang lebih tinggi dibandingkan tanpa menggunakan flow compensation. Sedangkan pada anatomi corpus vertebralis dan spinal cord diperoleh hasil mean rank yang sama antara menggunakan dan tanpa menggunakan flow compensation. Hal ini dikarenakan keterbatasan dari flow compensation dimana hanya terfokus meminimalisir artefak pada daerah aliran yang memiliki kecepatan atau percepatan [A. DG, 2001]

Penggunaan flow compensation cukup efektif dalam memperbaiki citra MRI
Cervical dikarenakan pada daerah cervical terdapat aliran dari csf yang cukup tinggi sehingga citra dapat terllihat lebih baik karena artefak yang berkurang pada citra MRI Cervical.

\section{Kesimpulan}

Terdapat perbedaan pada pemberian antara menggunakan flow compensation dan tanpa flow compensation, serta berkurangnnya flow artefak pada MRI Cervical. Pengurangan flow artefak pada MRI Cervical terdapat pada citra yang menggunakan flow compensation ditunjukkan dengan nilai p-value 0,001 (p-value $\leq 0,05)$.

Antomi citra dapat terlihat lebih baik pada sekuen T2 FSE MRI Cervical potongan axial dan sagital secara umum yang menggunakan flow compensation tetapi pada anatomi corpus vertebralis dan spinal cord potongan sagital tidak terdapat beda signifikan antara menggunakan dan tanpa menggunakan flow compensation.

\section{Daftar Pustaka}

A DG, "Practical Statistics for Medical Research," Chapman and Hall, 1991.

Blink and Evert J, Basic MRI : Physic Aplication Specialist MRI., Netherlands, 2004.

Covington and Mattew T, "Feasibility Study of Flow Compensation to Improve Diagostic Quality of $\mathrm{T} 1$ post Spine Echo MRI Through the Posterior Fossa," American Research Institute for Policy Development, 2017.

C. Westbrook, . K. R. Carolyne and K Roth , Handbook of MRI Technique., United Kingdom: BLackwll Science Ltd, 2014..

Dale, M Brian, M.A Brown, Ricard C and Smelka, MRI Basic Principle and Applications Third Edition, New Jersey: John Wliey and Sons, 2015.

Fieldstrength 49, "CF Flow Compensation in Spine," no. Philip Applicarion Tips, 2013. 
J. Busherg, Leidholt E.M.J and Boone J.M, The Essential Physics of Medical Imaging 2nd Ed, Lippincott's William \& Wilkins, 2012.

M. Hussain, Nasir, Murtaza, Moeed, U and Bari, M, "Magnetic," 2012.

M. J. N, M. RungeVal, F. Ai, Attenberger Ulrike, Vu Lan, Schmeets Stuart, Nitz Wolfgang R and Krisch John E, "An Image-based Approach to Understanding the Phsics of MR Artifacts," radiographics.rsna.org, 2011.

P. Lotke, Lippincott's Primary Care Orthopaedics, China: Philadelphia, 2008.

P. J. C. L. e. a. Pattany PM, "Motion artifact suppression technique Suppression Technique (MAST) for Imaging," $J J$ Comput Assist Tomograph, 1987. 